\title{
Lex Posterior and Lex Specialis Legal Maxims in Russian Criminal Law
}

\author{
Aleksandr A. Petrov* \\ Siberian Federal University \\ 79 Svobodny, Krasnoyarsk, 660041, Russia
}

Received 28.09.2019, received in revised form 31.10.2019, accepted 11.11.2019

\begin{abstract}
The present article stipulates on various disputable issues of applying the general legal maxims on overcoming the conflict of lex posterior derogate priori and lex specialis derogate legi generali based on the empirical examples of contemporary Russian criminal law. The objective is to clear the peculiarities of operating the lex posterior and lex specialis maxims including, inter alia, through appealing to the doctrine and positive law in the aspect of correlation with some specific colnflict rules. For this purpose, the author turns to a number of techniques, ways and methods of legal phenomena studies, such as, particularly, system approach, ascend from abstract to specific, using the logic of standard and normative statements, conceptual and definition analysis, speculative experiment, legal and dogmatic approach, legal simulation method, law comparison method. The main conclusion of the research is formulated as follows: though the principles of lex specialis and lex posterior are generated by the legal doctrine as criteria for selecting one out of two conflicting options, the principle that a law governing a specific subject matter overrides a law governing only general matters finds a wider scope of application compared to the principle of priority of a new law over the old one. The situation is explained by the fact that lex specialis is deliberately used by the legislators to construct logical relationships of legal rules, while lex posterior does not perform a similar function.
\end{abstract}

Keywords: conflict of law and regulations, lex specialis, lex posterior, legal interpretation, retroactivity in law.

The article was prepared with financial support of Russian Foundation for Basic Research (RFBR), project No. 18-011-00583।18 "The Algorithm of Resolving of the Conflict of Law Rules in Case of Their Congruence".

Research area: theory and history of law and state; the history of the teachings of law and the state.

Citation: Petrov, A.A. (2019). Lex posterior and lex specialis legal maxims in Russian criminal law. J. Sib. Fed. Univ. Humanit. Soc. Sci., 12(11), 2058-2078. DOI: 10.17516/1997-1370-0512.

(C) Siberian Federal University. All rights reserved

* Corresponding author E-mail address: aapetrov@sfu-kras.ru ORCID: 0000-0003-3177-8918

This work is licensed under a Creative Commons Attribution-NonCommercial 4.0 International License (CC BY-NC 4.0). 


\section{Introduction}

In the present article the author studies the disputable issues of operating such general maxims for overcoming the conflict of law as lex specialis derogat legi generali and Lex posterior derogat priori based on the examples of contemporary Russian criminal law. A special attention is paid to the connection between the mentioned principles and specific conflict of law rules established in the criminal law (primarily, Part 3 Article 17 of the Criminal Code of the Russian Federation).

The objective of the study is to clarify the functioning specificity of the lex posterior and lex specialis conflict of law principles by appealing to the doctrine and positive law in the present sector and correlation to some certain collision rules.

There are two reasons why the examples were selected from criminal law. First of all, Part 3 Article 17 of the Criminal Law of the Russian Federation establishes, though in a limited manner, the lex specialis principle, while the lex posterior principle does not find application anywhere in the Code. May this circumstance take its toll on the role of each mentioned principle in the criminal and legal regulation? The second reason is the "testing integrity": the criminal and legal dogma of contemporary Russia is hardly vulnerable to any influence from the general legal theory or any other science in any possible way.

The author turns to a number of different techniques, ways and methods of studying the legal reality phenomena. They include: system approach, ascend from abstract to specific, using the logic of standard and normative statements, conceptual and definition analysis, speculative experiment, legal and dogmatic approach, legal simulation method, law comparison method.

In the present article, the author chooses not to consider the hierarchic conflict principle (lex superior derogate legi inferior), as no significant specificity of applying the principle in the criminal law has been found, unlike in lex specialis or lex posterior. It is mostly connected to the minor "level difference" in the legal relevance of the criminal law sources exclusively controlled by the Federation (Article 71 of the Constitution of the Russian Federation), and the fact that the only recognized criminal law of the country is the current Code (Part 1 Article 1 of the Criminal Code of the Russian Federation).

In the present study, the competing and conflicting law limitations are considered from a critical point of view, and it can be easily explained. In the so-called competing and conflicting law, the law enforcer expected to issue a resolution on the right faces several mismatching legal bases for such a resolution, and has to solve the problem of preferring one law and ignoring another, regardless of the reason for such mismatch: stupidity, intention or malevolent trick of the legislators. It does not change the essence 
of the conflict situation and the issue to be solved by the law enforcer, no matter how hard the supporters of the essential-conceptual division of conflicting and competing laws are trying to demonstrate the opposite.

\section{Discussion}

\subsection{Conflict of law rules and collision maxims (principles)}

One should distinguish between the conflict of law as a part of positive law and collision principles (maxims) as a result of sophisticated intellectual process of establishing the general and the legitimate in making a choice in the conflict of this or that law, based on an objectively set parameter.

The nature of conflict of law does not raise any principal questions. These are the positive law rules, sui generates, and it does not matter whether one prefers to refer to them as technical laws (A. Rozhdestvenky), regulators in the selection of law (A. A. Tille), rules of rules (A.F. Cherdantsev), secondary rules of law (O.F. Skakun), untypical rules of law (V.A. Rybakov), specialized laws fixing the models for some standard conflicts' solutions (N.A. Vlasenko), system-providing specific rules of law (A. V. Baranov) etc. The principal point is that there is no sense in denying their belonging to the body of positive law as normative-regulatory tools (Shafirov, 2013). The conflict of law rules are the specific rules for selecting the applicable legal regulation in the situation when the conflict of law occurs, which is understood as presence of several functionally mismatching legal regulations or sets of regulations governing one and the same actual situation. Besides being textually expressed in the explicit form of "context-connection", the conflict of law rule may be also derived of the interpretation of related sources of law.

In the international private law theory, it is common to classify the conflict of law rules into unilateral and bilateral. The difference between them is that the unilateral conflict of law rule does not allow for selection of foreign law as applicable (in any situation, only the law of the country where the court is situated, lex fori may be applied), while the bilateral conflict of law rule allows for choosing between the domestic and foreign laws on the basis of a specific set of parameters by appealing to a conflict of law rule (Luntz, 1949: 48-49).

The mentioned qualification of the conflict of law rules has a meaning for the general law theory and some sectoral theories as well. The fundamental difference between the unilateral and bilateral conflict of law rules is their roles in the process of conflict regulation determined by the diversity of conflict of law resolving strategies. Basically, 
unilateral conflicts of law rules are intended to legally avoid any conflicts, as they contain instructions for the law enforcers and other law addressees to ignore any other legal regulations except for the one set in the unilateral rule. It is interesting to remark that the operating regulations within the doctrine, specifying, for instance, the temporal and spatial limits of law application, are functionally close to the unilateral conflict of law rules. At the same time, the bilateral conflict of law rules, first of all, implicitly recognize that the legal regulations as such may conflict with each other, and, secondly, find the right answer to the question on applicable regulation based on specific variables of such regulation (date of enactment, hierarchic position, degree of specialty).

Compared to the conflict of law rules, the nature of collision maxims (Lex superior derogat legi inferior, Lex specialis derogat legi generali and Lex posteriori derogat legi priori) are a disputable matter.

Lawyers share the opinion that the mentioned conflict of law rules (maxims) act as intellectual tools for resolution of conflicts within one and the same system of justice (one legal system), which may be both national and international law (Michaels and Pauwelyn, 2012). However, if studied more thoroughly, the actual status of conflict principles is still vague even for outstanding law scientists, which is mostly explained by the tight connection between their conceptualization and the general legal consciousness context. For example, H. Kelsen changed his point of view on the nature of the conflict maxim lex posterior three times: in his early studies (before 1918), lex posterior was understood as a legal and logical principle; later, till the mid-1920s, based on the doctrine of his disciple A. Merckle, he insisted on the exclusively positivist nature of the priority of a later enacted regulation over the earlier enacted one; and then, until the second edition of his "Pure Theory of Law" was published, Kelsen considered lex posterior in a NeoKantian way, i. e. as an a priori pre-requisite for positive law cognition, and, in this sense, as a part of the postulated basic regulation underlying any legal system. Finally, after 1960, the Austrian-American thinker returned to the strictly positivist interpretation of the temporal collision principle he used to preach before the mid-1920s (Paulson, 1983).

In contemporary theory of law, the diversity of opinions on the general conflict of law resolution principles is really impressive. Thus, Austrian researcher E. Vranes studies a constellation of different opinions on the nature of such conflict of law rules ever presented in legal literature. The analysis carried out by E. Vranes (Vranes, 2005) demonstrates that sometimes the authors do not pay enough attention to the conceptual precision of the sequence and may therefore change their point of view or approach the nature of specific maxims in different ways. "Legal logic principles" (J. Heckman), "general legal 
principles" (V. Chaplinsky, G. Danilenko), "interpretation rules" (F. Bydlinski), "legal presumptions" (N. Bobbio), "conventionally applicable legal rules (H. Meyer), "legal customs" (F. Bydlinski), "mere legal proverbs" (G. Karic), "relatively non-differentiated methodological provisions with no legal power of their own (and therefore incapable of cancelling other regulations), being a simple expression of a comprehensive interaction of other rules" (D. Hekhman), "more of practical methods of searching for actual expression of the legislator's will" (K. Engisch): the diversity of approaches is truly amazing (see Vranes, 2005: 394-396). However, G. Schwarzenberger completely denies any special legal status of the conflict maxims (see Vranes, 2005: 395).

Obviously, such misalignment of the doctrinal approaches to the conflict maxim nature is not a coincidence. It is greatly determined by the sophisticated and controversial history of the mentioned principles. Without elaborating on hislty, one can remark that it would be wrong to consider the principles of lex superior, lex specialis and lex posterior as a fruit of some instantaneous conceptualization of the general approaches to the solution of conflicts of law carried out by, let's say, some Roman lawyers at the development of Justinian's Digests (in the Digests, on the opposite, the principles of lex posterior and lex specialis have different statuses, and, being even expressed in different languages, are never studied together; the lex superior principle is not even declared) (Halpérin, 2012). The comparative law history allows to speak of heterogeneity of specific collision maxims' genesis, while the question of their mutual correlation arises only when the homogeneity of such collision principles is recognized.

With due regard to the aforesaid, the basic questions concerning the nature of the studied maxims should be asked. Two would be enough: firstly, do these principles constitute a part of the positive law in the same sense as any other regulatory and normative tools? In other words, do they need positivisation (in this situation the nature of positivisation does not matter, it can be a law, or a legal tradition, or a legal position of one of the supreme courts)? And secondly, how do the described principles interact with certain conflict of law rules established in the positive law?

To find answers to these questions, let us turn to the manifestation of lex specialis and les posterior in the criminal law of Russia.

\subsection{Lex specialis in the criminal law of Russia}

The priority of the specific regulation over the general one has been established in Russian criminal law, but not completely. The subject matter is Part 3 Article 17 of the Criminal Code of the Russian Federation, according to which, if a crime is 
governed both generally and specifically, then cumulative crimes shall not be imposed and criminal liability shall be based on the specific elements.

Importantly, the legislator has limited the application of the lex specialis principle to the criminal law only to the Special Part of the Criminal Code of the Russian Federation, where, based on the specific delict principle, the criminal liability for a certain limited number of criminal deeds is established. In other words, the actual goal of the rule expressed in Part 3 Article 17 of the Criminal Code of the Russian Federation is to demonstrate, that in case of collision of the general and special regulations used to establish the criminal nature of a deed, there is no perfect cumulative crime, which means that a special provision, not a cumulation of general and special provisions, shall be applied. This is the way of interpreting this regulation by the Constitutional Court of the Russian Federation which, appealing to the non bis in idem interdisciplinary principle, tends to emphasize that the criminal law shall avoid repeated judgement and punishment of a person for one and the same crime, qualification of one and the same criminal deed under several articles of the criminal law if the regulations set out in them correlate with each other as the general and specific ones (Resolution of the Constitutional Law of the Russian Federation No. 2768-O dated October 25, 2018). Similar legal opinions of the supreme body of the constitutional law of Russia are formulated in the Decree of the Constitutional Court of the Russian Federation No. 3- $\Pi$ dated March 19, 2003, Decree of the Constitutional Court of the Russian Federation No. 2-П dated February 10, 2017, and the Resolution of the Constitutional Court of the Russian Federation No. 1541-O dated 18.07.2017.

The current opinion of the Russian criminal legal doctrine concerning qualification of a deed in a conflict between general and specific rules in the Special Part of the Criminal Law, was well formulated by A. N. Trainin: "always, and, doubtlessly, in the presence of two rules, with one of them implying a generic aspect and the other implying the specific, special aspect, a criminal deed shall be qualified under the specific, not general rule. The special factor dominates over the generic. The generic factor is therefore kept as a reserve for the situations not covered by the specific rules... The two summonses cannot make up a sum if one of them belongs to the generic, and another to the specific level" (Trainin, 2004: 185; see also: Zatsepin, 2016).

In this regard, N. F. Kuznetsova points out five rules of crime qualification in the situation when a choice between the general and specific rules is to be made.

"a) if the deed is foreseen by specific rule and by the majority of features by the general rule, it shall be qualified under the specific rule; 
b) the cumulative crime qualified under the general and specific rule is allowed when such cumulation is real. Qualification of the deed as an act complying with more than one definition is not allowed;

c) qualification under specific rules shall be based on the elements of offence listed in the general rule;

d) a deed shall be qualified under the general rule when there is no related specific rule;

e) contradictions between the general and specific rules arising through the fault of the legislator, when there are elements of the general rule that are not applicable for qualification of the deed under the special rules, shall be resolved in favour of the latter" (Kuznetsova, 2008: 119-120).

It is not hard to notice that all the principles of overcoming conflicts suggested by N.F. Kuznetsov only highlight and specify the underlying principle: specific law overrides the general one. Rule (e) is of special interest here, as it demonstrates the flexibility of conflict overcoming strategies available to the law enforcers: it turns out that in certain situations one may think "for" the legislator and practically create a conflict situation between the general and specific rules to avoid applying the general one.

However, does it mean that the lex specialis principle in criminal law only covers the provisions of the Special Part of the CC of the Russian Federation and is not applicable to the misalignment of the regulatory settings between the General and Special Parts of the Criminal Code and between the regulatory settings within the General part of the criminal law?

In the sectoral doctrine, a number of researchers give a positive answer to this question.

N. N. Marshakova consistently denies the applicability of the lex specialis principles beyond the Special Part of the Criminal Code of the Russian Federation. Particularly, she suggests completing Article 1 of the Criminal Code with the following rule: "In case of any contradictions between the provisions of the General and Special Parts of the Criminal Code, the priority shall be granted to the General part provisions, except for the cases expressly provided for by the present Code" (Marshakova, 2006: 6). However, the researcher does not provide any sufficient justification to this opinion (except for the reference to positive law).

According to N.F. Kuznetsova, in case of misalignment of the General and Specific rules of the Criminal Code, the Special ones shall be applied, as they cover all the rules of the Special Part of the Criminal Code without any exceptions (Kuznetsova, 2008: 123). It is worthwhile noticing that the position of the author is inconsistent: in the next 
sentence, comparing the provisions of Articles $282^{1}, 210$ and 35 of the Criminal Code of the Russian Federation, N.F. Kuznetsova suggests to grant the priority to the provisions of the Special Part of the Criminal Code, excusing such an exception ad hoc with the necessity to "correct" the obvious error of the legislator (Kuznetsova, 2008: 123). Of course, such hasty revisionism discredits the idea of the priority of General Rules of the General Part of the Criminal Code over the rules of the Special Part as such.

However, the doctrine also suggests another approach to interpreting the application scope of lex specialis in criminal law, which is about spreading the idea of priority of the specific rule over the general beyond the limits of the Special Part of the Criminal Code.

Thus, V.F. Shepelkov remarks that even though "in the current legislation the specific rule term is applied only to the provisions of the Special Part (Part 3 Article 17 of the Criminal Code of the Russian Federation), while in fact the interpretation of laws as "general-specific" shall be understood in a wider way, as also applicable to the provisions of the General Part" (Shepelkov, 2003: 64).

Comparing the general principles of imposing punishments in Articles 60 and 64 of the Criminal Code, L. V. Inogamova-Hegai indicates that in case of conflict of the general and specific rules, the specific one shall be applied even if the rules of the General Part of the Criminal Code are misaligned. In the first (lex generalis), the subject matter is the determination of the amount of penalty within the sanctions imposed by the Special Part provisions, while the second (lex specialis) allows for imposing a punishment at a smaller amount than the minimum sanction of the provisions of the Special Part of the Criminal Code. In case of a conflict with the rules of Article 60, the rule of Article 64 shall be applied (Inogamova-Hegai, 2015: 47).

Agreeing with the universalization of the special rules' overriding the general ones in the criminal and legal regulation, M.P. Pronina formulates quite a peculiar conceptual restriction: "The suggested rule [of the universal priority of lex specialis] may be accepted only in the part that is not related to the essential elements of the offence. For instance, if the sanctions of an article from the Special Part imposes a punishment at the amount exceeding its maximum value established by the General Part of the Criminal Code, it is obvious that the General Part should be taken as a priority" (Pronina, 2017: 546). However, the reasons why it should be so obvious remain unexplained.

Criticising the idea that in a conflict between the general and special grounds for exoneration of juveniles, the general, not special rule shall be applied, E. V. Blagov 
explains that it contradicts Part 3 Article 17 of the CC (Blagov, 2003: 229), and at the same time he interprets Part 3 Article 17 of the Criminal Code in a wider way.

How is the issue resolved in the judicial practice? It is complicated.

For instance, in Par. 29 of the Decree No. 2 of the Plenum of the Supreme Court of the Russian Federation "On Practice of Imposing Punishment by the Courts of the Russian Federation" dated January 11, 2007, and provided that the conflict between the general (Part 4, Article 56 of the Criminal Code) and special (Part 3, Article 69 of the Criminal Code) rules on the possible maximum penalty for the cumulative crime, the priority shall be granted to the general rule, not the special one (Neznamova, 2012b: 90).

However, in Par. 7 of the Decree No. 19 of the Plenum of the Supreme Court of the Russian Federation "On Application of the Legislation Regulating the Grounds and Order for Exoneration by Courts" dated June 27, 2013, we see the opposite approach, i. e. the priority of lex specialis: release from criminal liability for the crimes of little and medium gravity in the situation expressly provided for by the notes to the related articles of the Special Part of the Criminal Code shall be done according to the rules established by such notes. In that situation the satisfaction of the general conditions foreseen by Part 1 Article 75 of the Criminal Code is not required.

The aforesaid brings us to the conclusion that in criminal law the idea of priority of the specific rule over the general one is conceptually richer than the legislative formulation of the conflict of law rule presented in Part 3 Article 17 of the Criminal Code. The doctrine and the practice may sometimes expand its scope of application without bothering to seek for any ultimate grounds for such interpretation, referring mostly to the general idea of justice and humanism principles. In this situation, partial positivisation of the lex specialis principle in Part 3 Article 17 of the Criminal Code of the Russian Federation significantly simplifies the application process.

\subsection{The lex posterior principle in the criminal law of Russia.}

Is the retroactivity of the criminal legislation an exception

\section{to this principle?}

The text of the criminal law does not contain the conflict principle lex posteriori derogat priori, unlike the previously considered lex specialis principle. The science of criminal law almost always thematically relates understanding of temporal conflicts of rules to the effect of criminal law in time (Neznamova, 2012a). This allows, for example, V.P. Malkov to argue that the lex posterior principle is applied in criminal 
law in a situation of "competition of rules in time, when they regulate the issue that is not related to the definition of crime and penalty for an act, but they [the rules] come from the same body" (Malkov, 2011: 433-434).

With this approach, the rules established in Articles 9 and 10 of the $\mathrm{CC}$ of the Russian Federation governing the issues of the operation of the criminal law in time (crime and punishment are determined by the criminal law in force at the time of the commission of an act (Part 1 Article 9 of the Criminal Code of the Russian Federation); criminal law eliminating the criminality of an act mitigating the punishment, or otherwise improving the situation of the person who committed the crime, has a retroactive effect, that is, it applies to people who committed relevant acts before the entry into force of such a law, including people who are serving or who have served their sentences but have a criminal record (Part 1 Article 10 of the Criminal Code of the Russian Federation)) are often treated as special (other than the lex posterior) rules to overcome temporal conflicts typical only for the criminal regulation. This point of view is found in both legal (Tille, 1965: 39: Kasatkin and Lushina, 2018, 144) and criminal law literature (Inogamova-Hegai, 1999: 35, 41-42; Neznamova, 2012a).

Let us investigate if the provision of Part 1 Article 9 and Part 1 Article 10 of the CC of the Russian Federation can be considered as specific (special) rules for overcoming temporal conflict of rules of law acting only in criminal law and being significantly different from the lex posterior principle.

Here it will be helpful to turn to the general context of understanding the conflict of law rules. As noted above (2.1.), there is a difference between unilateral and bilateral conflict of law rules. The first ones are "connected" with legal relationship to a predetermined law or order, thereby eliminating the conflict problem. The second ones are the rules for choosing the applicable law in the case when there is a conflict of law, i. e. several functionally inconsistent rules of law claim to regulate the same situation.

The purpose of the rule of Part 1 Article 9 of the CC of the Russian Federation does not include determining an objectively given chronological parameter for choosing the applicable rule in case of conflict, but in linking the current criminal law to the time of the commission of a criminal act. In other words, Part 1 Article 9 of the $\mathrm{CC}$ is intended to link a specific criminal law and a specific act in a temporary coordinate system. Moreover, the action of the rule of Part 1 Article 9 of the $\mathrm{CC}$ of the Russian Federation assumes the presence of only one valid criminal law at a time (during the commission of a criminal act), which regulates the legal relationship. Therefore, Part 1 Article 9 of the $\mathrm{CC}$ of the Russian Federation contains a unilateral conflict of law 
rule that eliminates the issue of temporal conflict of criminal law rules (the content and degree of consistency of criminal laws adopted previously and later, are not important since crime and the punishment of an act are determined by the criminal law in force at the time of the commission of this act).

Moreover, it is easy to see that the rule of Part 1 Article 9 of the $\mathrm{CC}$ of the Russian Federation may well function without a temporal conflict of the valid rules of criminal law, while any bilateral conflict of law rule applies only in the case of functional inconsistency of the rules, each of which is legally valid at a given point in time and therefore claims to regulate legal relations. Hence it is logical that the most controversial issues that concern researchers studying the mechanism of action of the criminal law in time arise not from the logic of conflict regulation, but from specificity of the field (in particular, the most important is the issue of the time the act was committed, for example, in situations of continuous or ongoing crimes). Let us recall that any bilateral temporal conflict of law rule is detected and applied at the second stage of the development of the conflict situation, i. e. when a judge or another law enforcement officer discovers a conflict of simultaneous rules that claim to regulate the same situation.

On the other hand, the rule of Part 1 Article 9 of the $\mathrm{CC}$ of the Russian Federation will be powerless if it is found that there are inconsistencies between the two criminal legal provisions of the Criminal Code of the Russian Federation contained in earlier and later adopted laws and the commission of a future act that will be prohibited by both valid rules of law at the same time. This is especially relevant for determining the criminality and punishability of acts provided for by blanket criminal law prohibitions, when the temporal conflict will result from the inconsistency of specific regulatory rules, the violation of which forms the disposition of the criminal law prohibition.

Let us dwell on this idea in more detail. Let us imagine that the article of the Special Part of the Criminal Code of the Russian Federation contains a prohibition on the commission of a criminal act $\mathrm{D}$ by violating compulsory rules $\mathrm{N}$ prescribed in the regulations governing a certain area $s$. It is easy to imagine that several regulations $\mathrm{N} 1$ and $\mathrm{N} 2$ can be issued at different times to regulate this sphere $s$, none of them will be formally nullified, and the rules contained therein will be inconsistent. Since at the time of the commission of the alleged criminal act $\mathrm{D}$ both rules are legally valid, albeit in conflict with each other, the application of Part 1 Article 9 of the Criminal Code to resolve their conflict will not help, while both rules can determine the criminality and punishability of act D (see Fig. 1). 


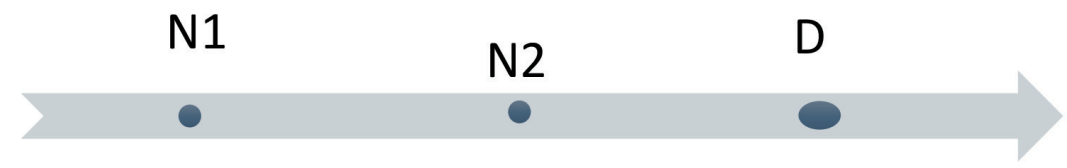

Fig. 1. Situation of typical temporal conflict (where N1 is a previously adopted criminal law, $\mathrm{N} 2$ is a later adopted criminal law, and $\mathrm{D}$ is an act)

Moreover, the same logic can be applied to the Criminal Code without applying blanket and reference regulation. Let us imagine, for example, that act $\mathrm{D}$ is prohibited by two mutually inconsistent rules (for example, in terms of types and (or) amount of punishment), one of which is contained in the original version of the Criminal Code of the Russian Federation (N1), and the second in one of the many federal laws modifying criminal codes (N2). Based on the provisions of Part 1 Article 9 it is impossible to resolve such a temporal conflict of law rules, since both prohibitions are part of the criminal law and are valid at the time the act was committed.

An example of such a large-scale temporal conflict is given by A. A. Tille. He notes that, paradoxically, when the 1964 RSFSR Criminal Code entered into force, the 1926 RSFSR Criminal Code was not formally abolished. This gave rise to the need to apply the principle that "the subsequent law is stronger than the previous one" to qualify acts committed after the introduction of the new Criminal Code of the RSFSR in 1964, precisely under this newer criminal law (Tille, 1965: 30).

The situation is a little more complicated with Part 1 Article 10 of the Criminal Code. Despite the fact that there is quite a widespread opinion in the literature that the rule on the retroactive effect of the "milder" criminal law is the branch temporal conflict of law rule different from lex posterior (Tille, 1965: 39, 54, 72, 161, 170-175; Bachrach, 2010: 50-52; Kasatkin and Lushina, 2018: 144; Inogamova-Hegai, 1999: 44; Inogamova-Hegai, 2015: 15-16; Neznamova, 2012a), it is difficult to agree with this approach. Let us give four arguments to support our view.

Firstly, although the rule of law on retroactive force at the first approximation can be taken as a bilateral temporal conflict of law rule, in reality it binds earlier and later adopted criminal laws through legal fiction of law replacement, which by virtue of Part 1 Article 9 of the CC of the Russian Federation should regulate the criminality and punishability of an act by another, later adopted and milder criminal law. We can say that the outwardly retroactive force of the milder criminal law is similar to the classical idea of the priority of the new law over the old one, but the basis for such a priority is 
completely different: the basis of the retroactive force of the milder criminal law is not the idea of the dynamism of the legal system and the need to supplant the old, outdated by the new and advanced, but humanism, compassion for the criminal or recognition and correction by the legislator of their own wrongfulness in the excessive severity of the criminal law (Tille, 1965: 75-78).

Secondly, the rule of Part 1 Article 10 of the Criminal Code is special in relation to the rule of Part 1 Article 9 of the Criminal Code. However, since the paragraph above had previously shown that Part 1 Article 9 of the Criminal Code does not contain an objective criterion for choosing one of the potentially applicable valid norms, then a special rule with respect to this rule of law cannot also be a bilateral conflict of law rule.

Thirdly, in the situation where the criminal law is retroactive, the conflict situation (when there are two valid and existing laws, each of which can be applied to make a decision on the case) simply does not have time to arise as a result of the implementation of the mentioned legal fiction of replacing the old criminal law with the new milder one, which allegedly acted at the time of the commission of the criminal act. Any conflict of law rule is needed to resolve the existing conflict of law, when each of the conflict rules occupying a certain place in the body of positive law, claims to dominate the legal relationship. In the case of the retroactive effect of the criminal law, there is no situation of functional incompatibility of simultaneously valid and existing criminal rules of law.

Finally, fourthly, from a comparative legal perspective, it will be interesting to note that even in those rare rules of law in which the principle of lex posteriori derogate priori is denied, it is quite possible to effectively regulate the effect of the criminal law in time, similar to the degree of confusion with the Russian one. We are talking about the legal system of the Republic of Armenia. Part 1 Article 40 of the Law of the Republic of Armenia of 2018 "On Regulatory Legal Acts" determines that in the event of a conflict between regulatory legal acts, the rule of law that entered into force earlier should be applied. The priority of the previously adopted rule over the one that was adopted later is set. The previous Law of the Republic of Armenia "On Legal Acts" of 2002 included a similar rule: according to Part 3 Article 24, a new legislative act adopted by the same body shall not contradict legal acts having equal legal force, adopted earlier and entered into legal force. If there are any contradictions between the legal regulatory acts adopted by the same body and having equal legal force, the rule of law of the legal act that entered into legal force earlier shall apply. However, 
the Criminal Code of Armenia in 2003 in terms of the principles of operation of the criminal law duplicates and even develops the provisions of the Criminal Code of the Russian Federation. Therefore, Article 12 of the Criminal Code of Armenia stipulates that criminality and punishability of an act are determined by the criminal law in force at the time of its commission (Part 1), and Article 13 incudes the rules regarding the retroactive effect of the criminal law:

1. The law that eliminates the crime of an act, mitigates punishment or otherwise improves the situation of the person who committed a crime has a retroactive effect, i. e. it applies people who committed the relevant act before the entry into force of such a law, including those serving a sentence or having served it, but having a criminal record.

2. The law establishing the criminality of an act, increasing the punishment or otherwise worsening the situation of the person who committed a crime does not have a retroactive effect.

3. The law that partially mitigates liability and at the same time partially enhances liability is retroactive only in the part that mitigates liability.

The foregoing can only be explained by the different nature of the rules on the operation of the law in time (as unilateral conflict of law rules) and bilateral temporal conflict of law rules reflecting the lex posterior principle.

Therefore, despite the lack of positivisation of the lex posterior principle in criminal law, the specified criterion for overcoming temporal conflicts is applied in criminal law, while any specific temporal conflict criteria for verification turn out to be not bilateral, but unilateral conflict of law rules aimed at eliminating the conflict situation. They alone do not prevent the use of the lex posterior maxim in case of a temporal conflict of criminal law.

\subsection{Demystification of the humanist criterion for determining temporal and content conflicts in the criminal law}

In professional literature, a theoretical position is sometimes found that in order to overcome conflicts in criminal law, a humanist criterion is used, according to which, in a conflict of two criminal law rules and the uncertainty of a criterion for selecting applicable rule, preference should be given to the one that is most beneficial (mild) for the person involved in responsibility. It is this idea that lies, for example, in the basis of the priority of the privileged components over the qualified ones in the case of the so-called competition of special rules. 
In particular, N.F. Kuznetsova believes that in criminal law there is a special humanistic sectoral principle of overcoming conflicts, which operates both in conflicts within the rules of the general and special parts of the criminal law. Its essence lies in the qualification of a less strict rule of the Criminal Code in the event of an internal regulatory conflict (Kuznetsova, 2008: 125). Similar thoughts are expressed by L. V. Inogamova-Hegai, who claims that the basis of this criterion is the interpretation of fatal doubts about guilt in favour of the accused, the principle of guilt, justice and retroactive effect of a milder criminal law (Inogamova-Hegai, 2015).

It seems that the situation is that the "use" of the so-called humanist criterion covers completely different processes that occur when choosing an applicable rule of law in a situation of their meaningful conflict.

First of all, let us note that there is one significant drawback in the concept of the possibility of a conflict between two special rules. Namely, the third — general — rule is ignored, in relation to which the two indicated rules are special.

Let us give a classical example. Part 1 Article 105 of the Criminal Code establishes a general prohibition on the commission of intentional homicide. Regarding this rule, both "qualified" killings (Part 2 Article 105 of the Criminal Code of the Russian Federation) and "privileged" killings (5 elements stipulated by Articles 106-108 of the Criminal Code of the Russian Federation) will be special. How then should the killing of two persons be qualified (Part 2 Article 105 of the Criminal Code of the Russian Federation) committed when the limits of necessary defence are exceeded (Part 1 Article 108 of the Criminal Code of the Russian Federation)? Both doctrine and judicial practice insist that in this case there is a competition of special rules that set the privileged and qualified elements, which is decided in favour of the privileged ones: an act must be qualified only in accordance with Part 1 Article 108 of the Criminal Code.

However, in the chain of reasoning, which leads to this conclusion, there is one weak link. Both the current criminal law and the prevailing dogma cannot explain why the choice arises between special rules of law, which are not inconsistent with each other: they just prohibit separate, different acts complementing each other, and nothing more. For a conflict situation to arise in the described case, a third, general rule should be present, with which each of the special rules will be mismatched.

Then two meaningful conflicts are revealed: (1) of general and "privileged" special and of (2) general and "qualified" special. The lex specialis principle states that each of these conflicts should be resolved in favour of the special rule. Thus, strictly speaking, by virtue of the direct instructions of Part 2 Article 17 of the Criminal Code in this 
case there is an ideal combination of privileged and qualified elements of crime. By virtue of Part 1 Article 17 of the Criminal Code of the Russian Federation in case of a combination of crimes, the person is criminally liable for each crime committed under the relevant article or part of the article of this Code. This is the result of a literal interpretation of the criminal law.

However, both doctrine and judicial practice, as was shown above, proceed from a completely different logic of legal regulation: an act is qualified only according to a "privileged" special rule.

This indicates that in order to overcome the conflict of criminal law rules in the described case, two strategies are simultaneously used:

(1) The strategy of choice and application of a special "privileged" rule of the CC of the Russian Federation in case of its conflict with the general rule (based on Part 3 Article 17 of the CC of the Russian Federation);

(2) The strategy of ignoring the presence of a conflict between the general rule and the "qualified" special rule.

Therefore, we have a curious example of using several strategies simultaneously in order to overcome conflicts (Petrov, 2017). The law enforcer as "does not see" the ideal combination of the crimes and rejects qualification in accordance with a stricter rule. This is where "humanism" lies in the situation of inconsistency of general and several special criminal law rules.

Let us also note that the humanist criterion for overcoming conflicts in criminal law does not pass the test for universal application.

In particular, when it comes to intersectoral conflicts between the provisions of the Criminal Code and the Administrative Offenses Code of the Russian Federation in the presence of a conflict between the rules establishing the wrongfulness of an act contained both in the $\mathrm{CC}$ and the $\mathrm{AOC}$, the doctrine and judicial practice, despite the legal position of the Supreme Court of the Russian Federation (see Paragraph 12.1 of the Decree No. 25 of the Plenum of the Supreme Court of the Russian Federation dated December 9, 2008 "On judicial practice in cases of crimes related to violation of the traffic code and operation of vehicles, as well as their unlawful seizure of the latter for the purpose of theft"), in general, they proceed from the need for qualification of an act under the Criminal Code of the Russian Federation, although in the Administrative Offenses Code of the Russian Federation a provision that would impose such qualification on law enforcement officials is not provided as clearly as the previously existing rule of Part 2 Article 10 of the Administrative Offenses Code of the RSFSR: 
by virtue of Paragraph 7 Part 1 Article 24.5. of the Administrative Offenses Code of the Russian Federation a case on administrative offense cannot be started, and the started proceedings must be terminated if there is an unlawful act (failure to act) on the same fact by the person against whom the administrative offense is being conducted, an order on commencement of a criminal case and initiation of proceedings (Shishko, 2003: 145-147).

The approach to solving the problem is based on the idea that "criminal wrongfulness absorbs all other types of wrongfulness and the latter lose their legal significance or exist separately, not merging with each other" (Pikurov, 1998: 5), therefore the Criminal Code of the Russian Federation has a priority (see Panov, 2013; Belov, 2002: 17). Paragraph 38 of the Judicial Practice Review No. 4 of the Supreme Court of the Russian Federation for 2017 is quite demonstrative (approved by the Presidium of the Supreme Court of the Russian Federation on November 15, 2017), in which the Supreme Court of the Russian Federation confirms the priority of the application of the Criminal Code to the Administrative Offenses Code of the Russian Federation just with reference to Paragraph 7 Part 1 Article 24.5. of the Administrative Offenses Code of the Russian Federation. It is noteworthy that even with the opposite approach, the priority of applying the Code of Administrative Offenses of the Russian Federation is usually justified by the fact that this code is a lex posterior with respect to the Criminal Code of the Russian Federation, but not the "mildness" of the Administrative Offenses Code of the Russian Federation for the offender (Mayevskiy, 2001).

Thus, the considered above shows that humanism is not a criterion for choosing a rule in the event of a conflict, but a value basis for choosing a specific strategy for the behaviour of the law enforcement officer who faced a conflict situation.

\section{Conclusion}

The foregoing allows us to conclude that despite the fact that the lex specialis and lex posterior principles are genetically generated by legal doctrine as criteria for choosing one of two rules in case of a conflict, the principle of priority of a special rule over a general one has a wider application in comparison with the principle of priority of a new law over the old one. The reason for this is that the creation of conflicts of general and special rules is deliberately used by the legislator as a sui generis legal and technical method, necessary for constructing the subsumption of legal rules, while lex posterior does not perform a similar regulatory function. 


\section{References}

Bachrach, D.N. (2010). Ocherki teorii rossiyskogo prava [Essays on legal theory of Russian law]. Moscow, Norma, 288 p.

Belov, M.N. (2002). Pravootnosheniya v ugolovnom prave [Legal attitudes in criminal law]. Nijniy Novgorod, $23 \mathrm{p}$.

Blagov, M.N. (2003). Obshaya teoriya primeneniya ugolovnogo prava [General theory of application of criminal law]. Yaroslavl, $260 \mathrm{p}$.

Halpérin, J.-L. (2012). Lex posterior derogat priori, lex specialis derogat generali. Jalons pour une histoire des conflits de norms centrée sur ces deux solutions concurrentes. In Revue d'Histoire du Droit [Legal History Review], 80 (3-4), 353-397. DOI: 10.1163/15718190-000A1212

Inogamova-Hegai, L.V. (1999). Konkurentsiya ugolovno-pravovykh norm [Competition between legal rules]. Moscow, 1999, 333 p.

Inogamova-Hegai, L.V. (2015). Kontseptualnyye osnovy konkurentsii ugolovnopravovykh norm [Concept of competition between legal rules]. Moscow, Norma, Infra-M, 2015, $288 \mathrm{p}$.

Kasatkin, S.N., Lushina, N.A. (2018). Temporalnyye yuridicheskiye kollizii [Temporal legal conflicts]. In Vestnik Samarskoy gumanitarnoy akademii. Seriya «Pravo» [Herald of Samara humanitarian academy: Law], 1 (20), 139-146.

Kuznetsova, N.F. (2008). Teoreticheskiye osnovy kvalifikatsii prestupleniy [Theoretical basis for the qualification of crimes]. In Polnyy kurs ugolovnogo prava [Crimanal law textbook]. Vol. 2. Saint-Petersburg, Yuridicheskiy tsentr Press, $22-127$.

Luntz, L.A. (1949). Mezhdunarodnoye chastnoye pravo. Uchebnik [Private international law. Textbook]. Moscow, Yuridicheskoye izdatelstvo Ministerstva yustitsii SSSR, $368 \mathrm{p}$.

Malkov, V.P. (2011). Izbrannyye trudy [Selected Works]. Vol. 2. Kazan, Poznanie, $524 \mathrm{p}$.

Marshakova, N.N. (2006). Klassifikatsiya v rossiyskom ugolovnom zakonodatelstve [Taxonomy in Russian criminal law]. Nijniy Novgorod, 30 p.

Mayevskiy, V. (2001). Zakon ne dolzhen protivorechit zdravomu smyslu [Law must not contradict common sense]. In Rossiyskaya yustitsiya [Russian justice], 5, 46-48.

Michaels, R., Pauwelyn, J. (2011-2012). Conflict of norms or conflict of laws?: different techniques in the fragmentation of public international law. In Duke Journal of Comparative \& International Law, 22, 349-376. 
Neznamova, Z.A. (2012). Problemy primeneniya obratnoy sily ugolovnogo zakona [On retroactivity in criminal law]. In Rossiyskiy yuridicheskiy zhurnal [Russian juridical journal], 4, 168-174.

Neznamova, Z.A. (2012). Sudebnoye tolkovaniye kak sposob preodoleniya kolliziy ugolovno-pravovykh norm [Judiciary interpretation as a way to resolve legal conflicts in criminal law]. In Rossiyskiy yuridicheskiy zhurnal [Russian juridical journal], 5, 86-92.

Nikiforova, A.A. (2017). Kollizii ugolovnogo i smezhnogo zakonodatelstva v ramkakh regulirovaniya vneshneekonomicheskoy deyatelnosti [Conflicts of foreign trade legal regulation by the criminal and others legislation]. In Yuridicheskaya tekhnika: ezhegodnik [Jurical technique: yearbook], 11, 676-678.

Panov, A.B. (2013). Spornyye voprosy privlecheniya k administrativnoy otvetstvennosti [Controversial issues of administrative responsibility. In Rossiyskiy sudia [Russian judge], 1, 28-32.

Paulson, S.L. (1983). On the status of the Lex Posterior Derogating Rule, in Liverpool Law Review, 5, 5-18.

Petrov, A.A. (2017). Strategii preodoleniya kolliziy v prave: ponyatiye. vidy. Effektivnost [On strategies of legal conflicts resolving: concept, taxonomy, efficiency]. In Yuridicheskaya tekhnika: ezhegodnik [Jurical technique: yearbook], 11, 262-264.

Pikurov, N.I. (1998). Kvalifikatsiya sledovatelem prestupleniy so smeshannoy protivopravnostyu [Investigator qualification of mixed wrongfulness crimes]. Volgograd, VSSh MVD SSSR, 54 p.

Pronina M.P. (2017). Kollizii v ugolovnom zakonodatel'stve kak izjan v yuridicheskoy tekhnike [Conflicts in criminal law as a flaw in jurical technique]. In Yuridicheskaya tekhnika: ezhegodnik [Jurical technique: yearbook], 11, 543-546.

Shafirov, V.M. (2013). Obshcheye ucheniye o norme prava i sovremennoye (integrativnoye) pravoponimaniye [Concept of legal norm and modern (integrative) notion of law]. In Voprosy pravovedeniya [Questions of jurisprudence], 2, 81-101.

Shepelkov, V.F. (2003). Ugolovnyy zakon kak formalno-logicheskaya Sistema [Criminal Code as a formal logical system]. Saint-Petersburg, 484 p.

Shishko, I.V. (2003). Konkurentsiya «ekonomicheskikh» norm UK RF s normami inykh otrasley zakonodatel'stva [Competition of "economic" norms of the Criminal Code of the Russian Federation with the norms of other branches of legislation]. In Pravovedenie [Jurisprudence], 5, 135-147. 
Tille, A.A. (1965). Vremya, prostranstvo, zakon. Deystviye sovetskogo zakona vo vremeni i prostranstve [Time, space, law. The effect of Soviet law in time and space]. Moscow, Iuridicheskaya literature, 208 p.

Trainin, A.N. (2004). Izbrannyye trudy [Selected Works]. Saint-Petersburg, Yuridicheskiy tsentr Press, 898 p.

Vranes, E. (2005). Lex Superior, Lex Specialis, Lex Posterior: Zur Rechtsnatur der “Konfliktlösungsregeln”. In Heidelberg Journal of International Law, 65, 391-405.

Zatsepin, A.M. (2016). Dopolnitelnaya kvalifikatsiya prestupleniya: obshchiye i spetsialnyye voprosy [General and particular issues of additional legal qualification in criminal law]. Moscow, Prospect, 304 p.

\title{
Коллизионные максимы lex posterior и lex specialis в отраслевом преломлении: \\ на опыте уголовного права России
}

\author{
А.А. Петров \\ Сибирский федеральный университет \\ Россия, 660041, Красноярск, пр. Свободный, 79
}

\begin{abstract}
В настоящей статье осмыслены различные спорные вопросы применения общеправовых максим преодоления коллизий юридических норм «специальная норма сильнее общей» и «последующая норма сильнее предыдущей» на эмпирическом материале уголовного права современной России. Цель работь - прояснить особенности функиионирования максим lex posterior и lex specialis, в том числе путем обращения к доктрине и позитивному праву в отраслевом срезе во взаимосвязи с конкретными коллизионными нормами. Для этого автор прибегает к различным приемам, способам и методам познания феноменов правовой реальности. Речь идет, в частности, о системном подходе, восхождении от абстрактного к конкретному, использовании логики норм и нормативных высказываний, концептуально-понятийном анализе, мыслительном эксперименте, юридико-догматическом методе, методе правового моделирования, сравнительно-правовом методе. Основной вывод исследования таков: несмотря на то, что принципы lex specialis и lex posterior порождены юридической доктриной как критерии выбора одной из двух норм в случае их коллизии, принцип приоритета специальной нормы над общей имеет более широкую сферу применения в сравнении с принципом приоритета нового закона над старым. Причина такого положения вещей заключается в том, что lex specialis умышленно используется законодателем для построения родовидовых связей правовых норм, тогда как lex posterior не выполняет аналогичной функции.
\end{abstract}

Ключевые слова: коллизии норм права, lex specialis, lex posterior, толкование права, peтроактивность в праве. 
Статья подготовлена при финансовой поддержке РФФИ, проект № 18-011-00583|18 «Алгоритм преодоления коллизий правовых норм в случае их совпадения».

Научная спещиальность: 12.00.01 - теория и история права и государства; история учений о праве и государстве. 